\title{
The effects of mesenchymal stem cells on the IDO, HLA-G and PD- L1 expression of breast tumor cells MDA-MB-231 and MCF-7
}

\author{
Mezenkimal kök hücrelerin, meme tümörü hücreleri MDA-MB-231 ve MCF-7'nin \\ IDO, HLA-G ve PD-L1 ifadeleri üzerine etkileri
Rabia Bilge Özgül Özdemir ${ }^{1}$, Alper Tunga Özdemir ${ }^{2}$, Cengiz Kırmaz ${ }^{3}$, Mehmet İbrahim Tuğlu ${ }^{4}$, Özgür Şenol ${ }^{5}$, Cenk Serhan Özverel ${ }^{6}$, Afig Berdeli ${ }^{2}$

Abstract

Aim: Mesenchymal stem cells (MSCs) are strong immunomodulatory cells and a component of the tumor microenvironment. In this study, we aimed to investigate the effects of MSCs derived from adipose tissue on the expressions of immune evasive molecules indoleamine 2,3-dioxygenase (IDO), human leukocyte antigen $\mathrm{G}$ (HLA-G) and programmed death-ligand 1 (PD-L1) of breast tumor cell lines MDA-MB-231 and MCF-7.

Methods: For this purpose, MSCs, MDA-MB-231 and MCF-7 cells were cultured with increased doses of interferon gamma (IFN-g). In another plate, tumor cells were cultured in transwell inserts using the same IFN-g stimulation to evaluate the effect of MSCs. At the end of the culture period, the HLA-G and PD-L1 expression was detected by flow cytometry, and IDO expression by the Luminex method.

Results: We found that in low-dose IFN-g stimulation $(10 \mathrm{ng} / \mathrm{mL})$, MSCs led to a significant increase in the HLA-G and PD-L1 expression of MCF-7 cells. On the contrary, at a high dose of IFN-g (50 ng/mL), their expression significantly decreased in both tumor cells. In addition, we observed that the IDO expression of MDA-MB-231 cells was significantly increased in the presence of MSCs, but MCF-7 cells were not affected. Conclusion: In conclusion, for MDA-MB-231 cells, MSCs may play a protective role because they reduce the expression of HLA-G and PD-L1 that are involved in the suppression of cytotoxic cells and exhaustion of T cells. On the other hand, MSCs may be an important source of high IDO levels, and therefore may negatively affect the antitumor immune response. However, our data should be supported by further studies.

Key words: Mesenchymal stem cells, immune evasion, HLA-G, PD-L1, IDO.
Öz

Amaç: Mezenkimal kök hücreler (MKH) güçlü immünomodülatör hücreleridir ve ayrıca tümör mikroçevresinin bir bileşenidir. Bu çalışmada meme tümör hücre hatları MDA-MB-231 ve MCF-7'nin immün evazif moleküller olan Indoleamine 2,3-dioxygenase (IDO), Human Leukocyte Antigen G (HLA-G) and Programmed DeathLigand 1 (PD-L1) ifadelerine yağ dokusu kökenli mezenkimal kök hücrelerin etkilerini araştırmayı amaçladık. Yöntemler: Bu amaçla MKH, MDA-MB-231 ve MCF-7 hücrelerini artan dozlarda interferon gama (IFN-g) ile kültüre edildi. Başka bir kültür kabında MKH'ler ile tümör hücreleri trans-well insertler ve aynı IFN-g uyarımı ile kültür edildi. Kültür süresinin bitiminde HLA-G ve PD-L1 ifadeleri flow-sitmotetri yöntemi ile IDO ifadeleri Luminex yöntemi ile analiz edildi.

Bulgular: Düşük dozlu IFN-g uyarımında (10 ng/mL), MSC'lerin MCF-7 hücrelerinin HLA-G ve PD-L1 ekspresyonunda önemli bir artışa yol açtığını bulduk. Aksine, yüksek doz IFN-g ile $(50 \mathrm{ng} / \mathrm{mL})$ bu ifadelerin her iki tümör hücresinde de önemli ölçüde azaldığını gördük. Ek olarak, MDA-MB-231 hücrelerinin IDO ekspresyonunun MSC'lerin varlığında anlamlı şekilde arttığını, ancak MCF-7 hücrelerinin etkilenmediği gördük. Sonuç: Sonuç olarak, MDA-MB-231 hücreleri için MSC'ler, sitotoksik hücrelerin baskılanmasında ve T hücrelerinin tükenmesinde önemli bir rol oynayan HLA-G ve PD-L1 ekspresyonunu azalttı̆̆ı için koruyucu bir rol oynayabilir. Öte yandan, MSC'ler yüksek IDO seviyeleri için önemli bir kaynak olabilir ve bu nedenle antitümör immün yanıtı olumsuz yönde etkileyebilir. Bununla birlikte, verilerimiz diğer çalışmalarla desteklenmelidir.

Anahtar Kelimeler: Mezenkimal kök hücreler, immün kaçınma, HLA-G, PD-L1, IDO
${ }^{1}$ Manisa City Hospital, Department of Allergy and Clinical Immunology, Manisa, Turkey. ${ }^{2}$ Ege University, Institute of Health Sciences, Department of Stem Cell, Izmir, Turkey.

${ }^{3}$ Manisa Celal Bayar University, School of Medicine, Department of Internal Medicine, Division of Allergy and Clinical Immunology, Manisa, Turkey.

${ }^{4}$ Manisa Celal Bayar University, School of Medicine, Department of Histology and Embryology, Manisa, Turkey.

${ }^{5}$ Ege University, Department of Biotechnology, İzmir, Turkey.

${ }^{6}$ Ege University, Department of Bioengineering, Izmir, Turkey.

\section{id}

RBÖÖ: 0000-0002-8171-3402

ATÖ: 0000-0002-7708-077X

CK: $0000-0001-8873-1681$

MіT: 0000-0002-0569-8415

ÖS: 0000-0002-1062-3290

CSÖ: 0000-0001-9932-4774

AB: 0000-0001-5627-6100

Ethics Committee Approval: This study was no human or animal study, no ethical approval has been taken.

Etik Kurul Onayı: Bu çalışma insan veya hayvan çalışması olmadığı için etik kurul onayı alınmamıştır.

Conflict of Interest: No conflict of interest was declared by the authors.

Çıkar Çatışması: Yazarlar çıkar çatışması bildirmemişlerdir.

Financial Disclosure: The authors declared that this project has been supported by Manisa Celal Bayar University, Scientific Research Projects Coordination Unit (Project number 2017-224).

Finansal Destek: Yazarlar bu çalışma için Manisa

Celal Bayar Universitesi, Bilimsel Projeler

Arastirma Koordinasyon biriminden destek aldıklarını beyan etmişlerdir (2017-224).

Gelis Tarihi / Received: 05.08.2019

Kabul Tarihi / Accepted: 06.11.2019

Yayın Tarihi / Published: 01.12.2019

Sorumlu yazar / Corresponding author: Alper Tunga Özdemir

Adres/Address: 5522 street No: Uncubozköy, Yunusemre, Manisa, Turkey.

e-posta: alpertungaozdemir@gmail.com

Tel/Phone: +905052973269

Fax: +902842357652

Copyright $\odot$ ACEM 


\section{Introduction}

Mesenchymal stem/stromal cells (MSCs) are adult cells that are able to differentiate chondrocytes, osteocyte sand adipocytes [1]. In addition to these regenerative abilities, MSCs are also strong immunomodulatory cells that show their effects in a non-selective and non-specific manner [2]. When MSCs migrate into the inflammatory sites, they start to produce immunosuppressive molecules, such as prostaglandin E2, indoleamine 2,3-dioxygenase (IDO), interleukin 10 (IL-10), transforming growth factor beta (TGF-b), hepatocyte growth factor, and soluble human leukocyte antigen G (HLA-G). These molecules affect almost all immune cells [3]. Adaptive immune cells; i.e., T helper (Th) 1, Th2 and Th17, which are responsible for the formation of allergies, asthma and autoimmune diseases, are efficiently suppressed by MSCs whereas regulatory $\mathrm{T}$ cells (Treg), which are involved in self-tolerance development, are stimulated by MSCs [4]. In presence of MSCs, antigen presentation functions of dendritic cells are impaired due to their immature state [5], and the cytotoxic effects of natural killer (NK) cells are suppressed [6]. With their strong immunomodulatory effects, MSCs are used in fatal conditions, such as steroid resistant graft versus host disease or autoimmune disorders; e.g., systemic lupus erythematosus, Crohn's disease, and ulcerative colitis [7].

Breast cancer (BC) is the most common cancer type in women, and several studies have been performed to investigate the interactions between MSCs and BC [8-10]. The mutational loads of tumor cells may lead to vulnerability to immune elimination. Most of these mutations are immunogenic and can easily be detected by cytotoxic lymphocytes (CTLs) [11]. In addition, tumor cells down-regulate the major histocompatibility antigen class I expression, which is an inhibitor of NK cells, and without this inhibition, tumor cells would be destroyed by the activated NK cells [12]. Despite these anti-tumor immune responses, tumor cells can still evade the immune system through the assistance of the microenvironment.

HLA-G it is crucial for fetal tolerance. HLA-G, expressed from trophoblast cells, inhibits immune cells and blocks cytotoxic effects of especially NK and CTL cells by interacting with their receptors; i.e., killer cell immunoglobulinlike receptor 2DL4 and immunoglobulin-like transcript 4 $[13,14]$. In addition, HLA-G expression is only detected in fetal tissues and almost never found in adult tissues. However, some immune privileged cells continue to express HLA-G, such as dendritic cells, MSCs and cornea $[13,15,16]$. Other cell surface molecules include cytotoxic T-lymphocyte-associated protein 4 (CTLA-4) and programed death ligand 1 (PD-L1), which are important in the development of self-tolerance in a healthy immune system. However, especially PD-L1 is strongly expressed in some tumor tissues, and interactions with PD-1 results in the suppression of T, NK and dendritic cells [17,18]. PD-1 receptors expressed on various immune cells, such as CD4/CD8 T, B, dendritic and monocyte/macrophage cells. PD1/PD-L1 interactions lead to the strong inhibition of these cells by the dephosphorylation of proximal signaling molecules and augmentation of PTEN expression [19]. In addition to surface molecules, some important inhibitory molecules are secreted, including IDO, IL-10, and TGF-b. Tryptophan is an essential amino acid for T cells, and IDO is an enzyme that metabolizes tryptophan to kynurenine. IDO enzyme activation leads to relative tryptophan starvation for immune cells, especially $\mathrm{T}$ cells [20]. Kynurenine is the ligand for the aryl hydrocarbon receptor of immune cells. This receptor-ligand interaction results in suppressing effector T lymphocytes, and activating Treg cells [21]. In most somatic cells, IDO is expressed in response to IFN$\mathrm{g}$ stimulation, and IDO plays a critical role in the protection of cells from over-reactive immune cells [22]. MSCs are a component of the tumor microenvironment and can contribute to the immune evasion of tumor cells or increase the metastasis rate by accelerating the epithelial-to-mesenchymal transition [9].

Adipose tissue is a good source for MSCs and is the main component of breast tissue. In this respect, breast tumors constitute a valuable model to demonstrate the interactions between BC and MSCs derived from adipose tissue.

In this study, we aimed to investigate the alterations in immune evasive molecules, namely IDO, HLA-G, and PD-L1 of MSCs, invasive BC cells (MDA-MB-231) and non-invasive BC cells (MCF-7) in certain inflammatory conditions by performing in vitro co-culture experiments.

\section{Material and methods}

\section{Cell culture}

Two commonly used breast cancer cell lines, MDAMB-231 (ATCC ${ }^{\circledR}$ HTB-26 ${ }^{\mathrm{TM}}$ ) and MCF-7 (ATCC ${ }^{\circledR}$ HTB$22^{\mathrm{TM}}$ ), and $\mathrm{MSCs}$ derived from human adipose tissue were purchased from the American Type Culture Collection (ATCC). MDA-MB-231 cells were selected as invasive cells and MCF cells for their non-invasive nature. To culture MDA-MB-231 cells and MSCs, $10 \%$ fetal bovine serum (FBS) (Biosera, USA, Cat\#FB-1001), $1 \%$ penicillin/streptomycin (Biosera, USA, Cat\#XC-A4122), and 1\% L-glutamine (Biosera, USA, Cat\#XCT1715) containing the DMEM-F12 medium (Biosera, USA, Cat\#LM-D1225) were used. MCF-7 cells were cultured using $10 \%$ FBS, $1 \%$ penicillin/streptomycin, and 1\% L-glutamine containing the RPMI-1640 medium (Biosera, USA, Cat\#LM$\mathrm{R} 1638$ ). All cells were cultured at $37{ }^{\circ} \mathrm{C}$ in a 5\% CO2 incubator for passage three, and the cell culture media were renewed every two days with fresh media (Figure 1).

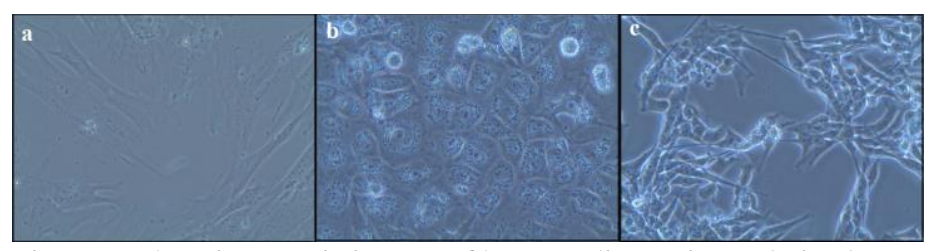

Figure 1: The microscopic images of human adipose tissue-derived mesenchymal stem cells (a), breast tumor cells MCF-7 (b), and MDAMB-231 (c)

To mimic the inflammatory condition, $1 \times 105$ cells of MDA-MB-231, MCF-7 and MSCs were separately cultured in 24-well plates with or without $10 \mathrm{ng} / \mathrm{ml}$ and $50 \mathrm{ng} / \mathrm{ml}$ human recombinant IFN-g (Reprokine Ltd, Israel Cat\# RKP01579) for 24 hours. In another plate, tumor cells were cultured with MSCs in $0.4 \mu \mathrm{m}$ pore-sized transwell inserts (Corning, USA, Cat\# CLS3378) using the same IFN-g stimulation to evaluate the effects of MSCs.

\section{FACS and Luminex analyses}

After the incubation period, conditioned medium supernatants were collected for the detection of IDO levels. All cells were detached using a trypsin-EDTA (Biosera, USA, Cat\#LM-T1705) solution and collected into individual tubes for flow cytometric analyses. To observe the alterations in the immune suppressor and co-inhibitory molecules, HLA-G (Clone: MEM-G/11; Exbio, Czech Republic) was stained with fluorescein isothiocyanate (FITC)-labeled monoclonal antibodies and PD-L1 (Clone: 29E.2A3; Exbio, Czech Republic) was 
stained with phycoerythrin (PE)-labeled monoclonal antibodies. Isotype negative IgG1 FITC (Clone: B-Z1, Diaclone, France) and IgG2a PE (Clone: B-Z2, Diaclone, France) controls were used to eliminate non-specific binding. The IDO levels were measured using an IDO Human ProcartaPlex ${ }^{\mathrm{TM}}$ Simplex Luminex kit (Invitrogen, USA Cat\# EPX01A-12213-901).

All FACS measurements were performed by a BD Accuri C6 device, and the analyses were undertaken using FlowJo v.10 software (BD Biosciences, USA). After choosing the appropriate cell population, the mean fluorescent intensity (MFI) values were calculated to evaluate the changes in the expression of HLA-G and PD-L1. The IDO levels were detected using a Luminex 200TM (Luminex Corp., USA) device, and the data were analyzed by xPonent v.3.1 software (Luminex Corp., USA). All experiments were performed in triplicate, and the detected values are summarized in Table- 1 .

Table 1: The results of the HLA-G, PD-L1 and IDO analyses of all experimental groups.

\begin{tabular}{lccc} 
& Unstimulated & $\begin{array}{c}\text { IFN-g (10 } \\
\text { ng/ml) }\end{array}$ & $\begin{array}{c}\text { IFN-g (50 } \\
\text { ng/ml) }\end{array}$ \\
\cline { 2 - 3 } & \multicolumn{2}{c}{ HLA-G (MFI) } \\
\cline { 2 - 3 } MDA-MB-31 & $1283.7 \pm 32.3$ & $1145 \pm 42.0$ & $1220.3 \pm 25.8$ \\
MSC Co-culture & $1355 \pm 50.1$ & $1083.66 \pm 28.1$ & $1065.3 \pm 11.0$ \\
MCF-7 & $2533.3 \pm 165.0$ & $2486 \pm 104.1$ & $2638.7 \pm 63.0$ \\
MSC Co-culture & $3106.3 \pm 82.7$ & $3479.3 \pm 109.3$ & $2678.3 \pm 102.8$
\end{tabular}

\section{PD-L1 (MFI)}

\begin{tabular}{lccc}
\cline { 2 - 3 } MDA-MB-231 & $173.7 \pm 8.5$ & $167.33 \pm 6.8$ & $187.3 \pm 5.0$ \\
MSC Co-culture & $161.3 \pm 6.5$ & $140.33 \pm 4.5$ & $171.7 \pm 3.5$ \\
MCF-7 & $181.7 \pm 6.5$ & $208.00 \pm 13.0$ & $255.3 \pm 12.1$ \\
MSC Co-culture & $183.7 \pm 8.1$ & $310.33 \pm 19.6$ & $171.7 \pm 7.6$ \\
& \multicolumn{2}{c}{ IDO (pg/ml) } \\
MDA-MB-231 & $0.01 \pm 0.0$ & $0.01 \pm 0.0$ & $0.03 \pm 0.02$ \\
MSC Co-culture & $0.023 \pm 0.015$ & $0.046 \pm 0.030$ & $1.74 \pm 0.24$ \\
MCF-7 & $0.05 \pm 0.03$ & $0.07 \pm 0.02$ & $0.09 \pm 0.05$ \\
MSC Co-culture & $0.03 \pm 0.01$ & $0.09 \pm 0.045$ & $0.13 \pm 0.05$
\end{tabular}

MFI: Median fluorescent intensity

\section{Statistical analysis}

GraphPad Prism software v.6 was used for the statistical analyses of the data sets. Descriptive analysis was performed to determine whether the groups were homogeneous. According to the Shapiro-Wilk normality test, the groups with a $\mathrm{p}$ of $>0.05$ or above were considered to be homogeneously distributed. The data were analyzed using the one-way analysis of variance method, and the results were considered significant when at $\mathrm{p}<$ 0.05 .

\section{Results}

The comparative HLA-G and PD-L1 histogram graphs of the FACS analysis of the experimental groups are shown in Figure-2, and the comparison graphs of HLA-G, PD-L1 MFI values and IDO Luminex results are given in Figure-3. The HLA-G MFI values of MCF-7 cells significantly increased in the unstimulated (US) MSC and IFNg-10/MSC co-culture groups compared to the US and IFNg-10 groups ( $\mathrm{p}=0.0004$ and $\mathrm{p}<0.0001$ respectively). However, there was no difference between the IFNg-50 and IFNg-50/MSC co-culture groups ( $\mathrm{p}=$ 0,9972). In addition, the HLA-G MFI values of the IFNg10/MSC co-culture group was significantly higher than the remaining groups. Among MDA-MB-231 cells, the highest HLA-G MFI value was detected in the US-MSC co-culture group. On the other hand, as a response to $10 \mathrm{ng} / \mathrm{ml} \mathrm{IFN-g}$ stimulation, the HLA-G expression of MDA-MB-231 cells was significantly decreased compared with the US groups $(\mathrm{p}=0.0032)$, but not in the IFNg-50 group. These decreases were more significant in the IFNg-10/MSC and IFNg-50/MSC coculture groups $(\mathrm{p}<0.0001$ and $\mathrm{p}<0.0001$, respectively) (Figure 2 and Figure 3).
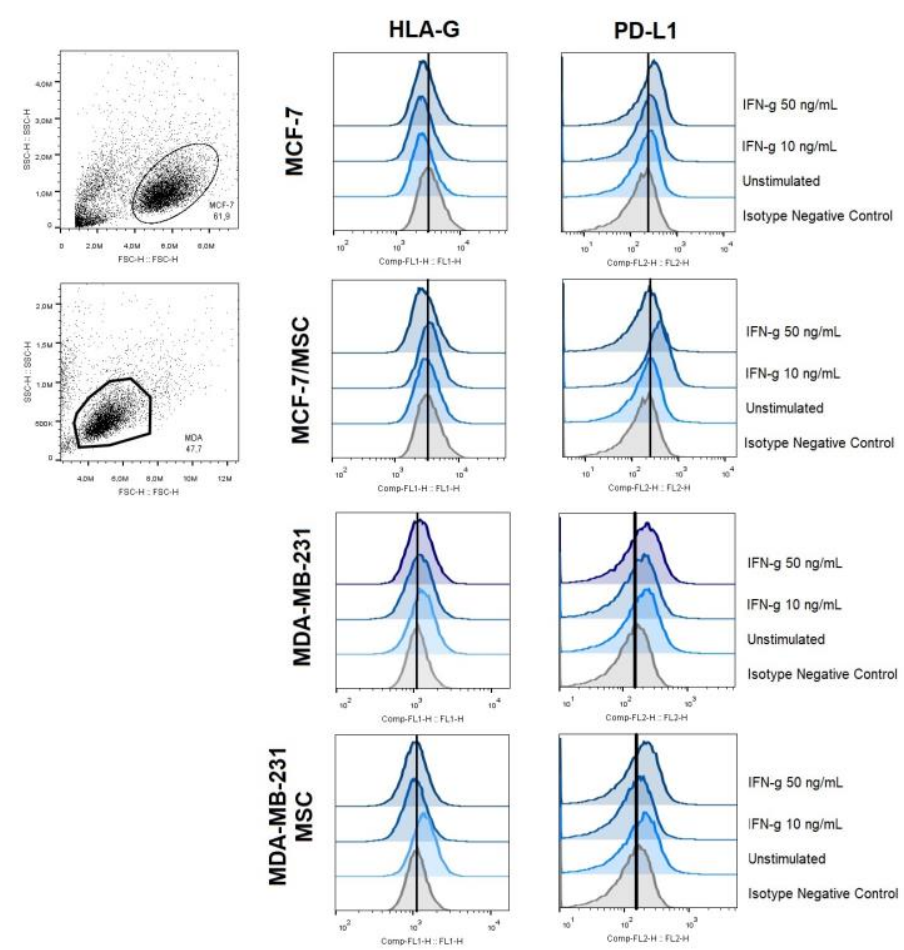

Figure 2: The histogram charts of HLA-G and PD-L1 flow cytometry analyses of MCF-7 and MDA-MB-231 cells with and without MSCs in different IFN-g stimulations.

We found no significant change in the PD-L1 MFI values of the US MCF-7 and US MCF-7/MSC groups. However, there was a significant increase in the IFN-10 group compared to IFN-10/MSC group ( $<$ 0.0001). Interestingly, this increase was reversed for the IFNg-50 and IFNg-50/MSC groups, and the PDL1 expression of MCF-7 cells was significantly decreased in the presence of MSCs ( $p<0.0001$ ) (Figure-2 and Figure-3). We detected that the PD-L1 expression of MDA-MB-231 cells was consistently reduced in the presence of MSCs. However, the difference was only significant between the IFNg-10 and IFNg10/MSC groups $(\mathrm{p}<0.0001)$.

We detected that the IDO expression of MCF-7 and MDA-MB-231 tumor cells were not affected by IFN-g stimulation. However, in the presence of MSCs, the IDO expression of MDA-MB-231 cells was significantly increased in response to $50 \mathrm{ng} / \mathrm{ml} \mathrm{IFN-g} \mathrm{stimulation} \mathrm{in} \mathrm{contrast} \mathrm{to} \mathrm{the}$ remaining groups ( $\mathrm{p}<0.0001$ for all groups).

\section{Discussion}

In this study, we stimulated breast tumor cell lines, MDA-MB-231 and MCF-7, with increased doses of IFN-g to mimic the inflammatory environment. We found that the HLA-G and PD-L1 expression of MDA-MB-231 and MCF-7 cells differed and was altered by the presence of MSCs. In addition, we observed that the IDO expression of breast tumor cells did not change after IFN-g stimulation; however; it significantly increased in the presence of MSCs.

There are numerous studies in the current literature about the relationship between HLA-G and tumor progression. Most have been performed using immunohistochemical methods 
and have reported a strong correlation between increased HLA-G expression and poor tumor prognosis $[15,23]$. In BC, HLA-G is

MCF-7
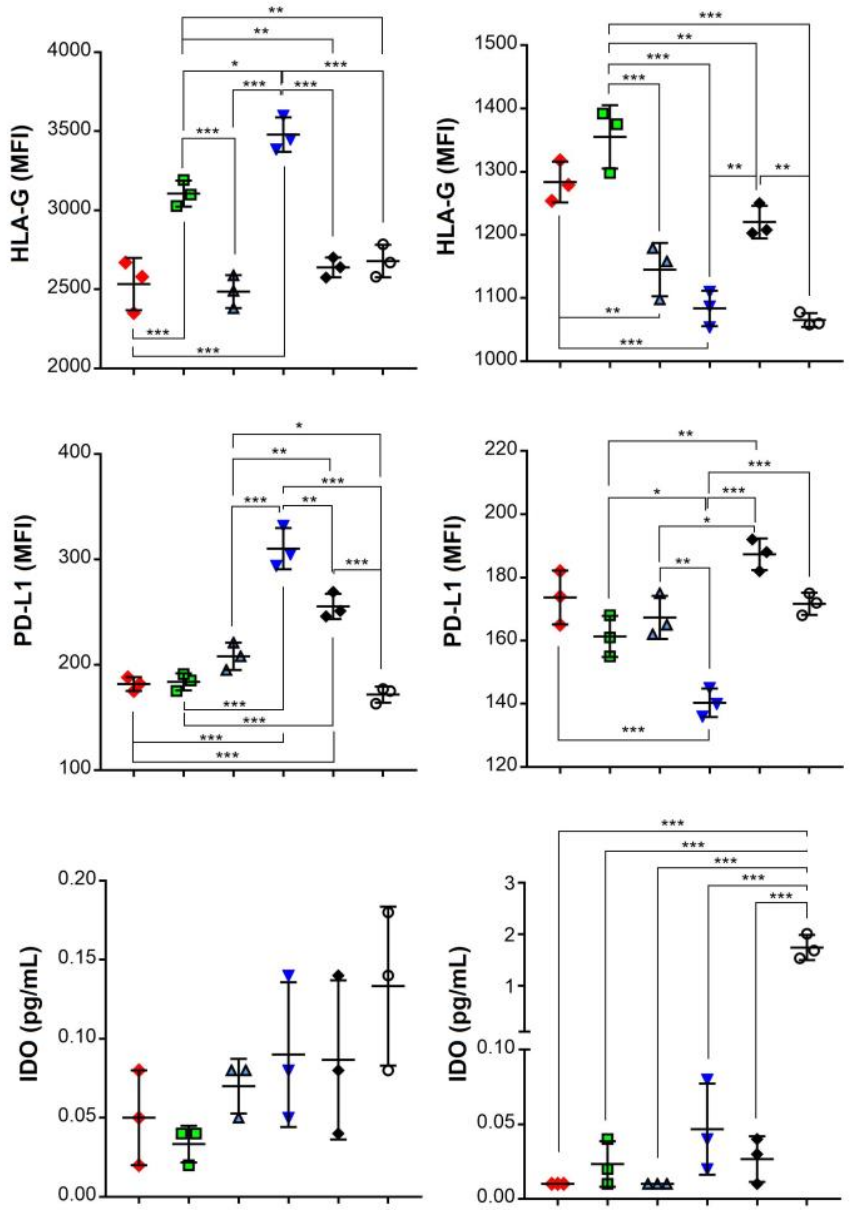

$\begin{array}{lllll}\text { US } & \Delta & \text { IFN-g }(10 \mathrm{ng} / \mathrm{ml}) & \bullet & \text { IFN-g }(50 \mathrm{ng} / \mathrm{ml}) \\ \text { a US-MCS } & \boldsymbol{\nabla} & \text { IFN-g }(10 \mathrm{ng} / \mathrm{ml})-\mathrm{MSC} & \circ & \text { IFN-g }(50 \mathrm{ng} / \mathrm{ml})-\mathrm{MSC}\end{array}$

Figure 3: The comparison charts of the HLA-G, PD-L1 and IDO expressions of MDA-MB-231 and MCF-7 cells with and without MSCs in different IFN-g stimulations. The data are presented as mean \pm standard deviation $(\mathrm{SD})(*$ statistically significant; $\mathrm{p}<0.05)$.

also associated with poor prognosis, and some researchers determined that HLA-G might be increased in a subset of tumor cells called cancer stem cells [24,25]. Based on the literature data, we investigated the HLA-G expression status of IFN-gstimulated invasive breast tumor cells; i.e., MDA-MB-231 and non-invasive MCF-7 cells and explored how MSCs affected this status. There are a very low number of reports on the HLA-G expression of these cell lines. Elliott et al. showed that MDAMB-231 and MCF-7 cells were be expressed by the mRNA of HLA-G in contrast to healthy breast tissue [26]. Our experiments confirmed that MDA-MB-231 cells had HLA-G expression, and this basal expression significantly decreased through IFN-g stimulation. In addition, we observed that this inhibition was stronger when IFN-g and MSCs were combined (Figure 2 and 3). According to our data, the HLA-G expression of MDA-MB-231 cells was significantly suppressed by IFN-g stimulation, which was potentiated by the presence of MSCs. The other breast tumor cell line MCF-7 is considered as non-invasive and has been shown to also express HLA-G [24,27]. In our experiments, we found that the HLA-G expression of MCF-7 cells did not change after IFN-g stimulation in a dose-dependent manner. However, we observed a significant increase in the HLA-G expression of the US-MCF and IFNg-10/MSC groups caused by MSCs. Interestingly, the MSC-induced HLA-G increase was not present in the IFN-g-50 group. According to our findings, MSCs seem to be an important factor for HLA-G expression in the basal and low-density inflammation of MFC-7 cells. However, this positive effect may be lost in high-intensity inflammation (Figure-2 and 3). In this study, we were not able to perform a cytotoxicity assay, but the possibility of occurrence of cell death due to high IFN-g stimulation applied should be considered.

Another important immune evasive molecule of tumor cells is PD-L1, which is expressed in many tumor types, including breast tumor cells. There are many studies on the expression of PD-L1 in breast tumor cells, particularly in MDAMB-231 and MCF-7 cells [28,29]. It was shown that IFN-g with pleiotropic effects increased the levels of immunosuppressive molecules, IDO, PD-L1 and CTLA-4, thereby limiting T cell functions [30,31]. In our study, we observed that both MDAMB-231 and MCF-7 cells expressed PD-L1, and this expression significantly increased after $50 \mathrm{ng} / \mathrm{ml}$ IFN-g stimulation, but not after $10 \mathrm{ng} / \mathrm{ml}$ IFN-g. We consider that this finding may be due to the pleiotropic effect of IFN-g. The PD-L1 expression of MDA-MB-231 cells may have been significantly reduced in the presence of MSCs, and this decrease may not have been related to IFN-g stimulation. As a result, the interaction between MSCs and MDA-MB-231 cells in response to IFN-g stimulation, may result in more efficient suppression of both HLA-G and PD-L1 expression. Similar to HLA-G expression, the PD-L1 expression of MCF-7 cells significantly increased in the IFNg-10/MSC coculture group and significantly decreased in the IFNg-50/MSC co-culture group. This finding suggests that IFN-g levels may be a critical factor in the interaction between MCF-7 and MSCs (Figure 2).

In many studies, tumor cells have also been shown to express IDO. However, the main sources of IDO in tumor tissue are tumor microenvironment cells, such as tumor-associated macrophages, cancer-associated fibroblasts, myeloid-derived suppressor cells, and MSCs [32,33]. It has been reported that the expression of IDO in breast tumor tissues are correlated with advanced tumor stage and poor prognosis [34]. In addition, the IDO mRNA expression has been detected in breast tumor cells lines, MDA-MB-231 and MCF-7 [35]. In this study, we investigate the contribution of MSCs to the IDO expression of tumor cells and found that the basal IDO expression of both MDA-MB-231 and MCF-7 cells was not affected by increased levels of IFN-g stimulation. However, we also determined that the IDO levels of the IFNg-50/MSC group were significantly higher in MDA-MB-231 cells than the remaining groups. The IDO expression of MCF-7 cells was unchanged in the presence of MSCs. This finding indicates that when the MSCs interacting with MDA-MB-231 cells, MSCs may be the main source of IDO expression.

In conclusion, the responses of two different breast tumor cells for the molecules investigated greatly differed. We found that MSCs interacting with MCF-7 cells significantly increased the HLA-G and PDL-1 expression in the presence of low IFN-g stimulation, but high IFN-g stimulation reversed this effect. The interaction of MDA-MB-231 cells with MSCs resulted in a significant reduction in the HLA-G and PD-L1 expression. In MDA-MB-231 cells, MSCs play a protective role because they reduce the expression of HLA-G and PD-L1 that are involved in the suppression of cytotoxic cells and exhaustion of $\mathrm{T}$ cells. However, MSCs may be an important source of increased IDO levels, and therefore may suppress the anti-tumor immune response. The data of our study were obtained only from the interactions of tumor cells and MSCs. In order to confirm our data and provide a better understanding of the contribution of MSCs to tumor immune evasion, further studies including immune cells are needed. 
Acknowledgements: This project was supported by the Scientific Research Projects Coordination Unit of Manisa Celal Bayar University (Project number 2017-224).

We would like to thank Dr. Ayşe Nalbantsoy for her help in flow cytometry analyses.

\section{References}

1. Dominici M, Le Blanc K, Mueller I, Slaper-Cortenbach I, Marini F, Krause D, Deans R, Keating A, Prockop D, Horwitz E. Minimal criteria for defining multipotent mesenchymal stromal cells. The International Society for Cellular Therapy position statement. Cytotherapy 2006;8:315-7.

2. Sangiorgi B, Panepucci RA. Modulation of Immunoregulatory Properties of Mesenchymal Stromal Cells by Toll-Like Receptors: Potential Applications on GVHD. Stem Cells Int. 2016;2016:e9434250.

3. Chen P-M, Yen M-L, Liu K-J, Sytwu H-K, Yen B-L. Immunomodulatory properties of human adult and fetal multipotent mesenchymal stem cells. J Biomed Sci. 2011;18:49.

4. Gao F, Chiu SM, Motan D a. L, Zhang Z, Chen L, Ji H-L, et al. Mesenchymal stem cells and immunomodulation: current status and future prospects. Cell Death Dis. 2016;7:e2062.

5. Özdemir RBÖ, Özdemir AT, Sarıboyacı AE, Uysal O, Tuğlu Mİ, Kirmaz C. The investigation of immunomodulatory effects of adipose tissue mesenchymal stem cell educated macrophages on the CD4 T cells. Immunobiology. 2019;224:585-94.

6. Castro-Manrreza ME, Montesinos JJ. Immunoregulation by Mesenchymal Stem Cells: Biological Aspects and Clinical Applications. J Immunol Res. 2015; 2015:e394917.

7. Erbey F, Atay D, Akcay A, Ovali E, Ozturk G. Mesenchymal Stem Cell Treatment for Steroid Refractory Graft-versus-Host Disease in Children: A Pilot and First Study from Turkey. Stem Cells Int 2016;2016:1641402.

8. Karnoub AE, Dash AB, Vo AP, Sullivan A, Brooks MW, Bell GW, Richardson AL, Polyak K, Tubo R, Weinberg RA. Mesenchymal stem cells within tumour stroma promote breast cancer metastasis. Nature. 2007;449:557-63.

9. Ridge SM, Sullivan FJ, Glynn SA. Mesenchymal stem cells: key players in cancer progression. Mol Cancer. 2017;16:31.

10. Wang Y, Liu J, Jiang Q, Deng J, Xu F, Chen X, et al. Human adipose-derived mesenchymal stem cell-secreted CXCL1 and CXCL8 facilitate breast tumor growth by promoting angiogenesis. Stem Cells. 2017;35:2060-70.

11. Brown SD, Warren RL, Gibb EA, Martin SD, Spinelli JJ, Nelson $\mathrm{BH}$, et al. Neo-antigens predicted by tumor genome meta-analysis correlate with increased patient survival. Genome Res. 2014;24:743-50.

12. Dahlberg CIM, Sarhan D, Chrobok M, Duru AD, Alici E. Natural Killer Cell-Based Therapies Targeting Cancer: Possible Strategies to Gain and Sustain Anti-Tumor Activity. NK Cell Biol. 2015;6:605.

13. Eskicioğlu F, Özdemir AT, Özdemir RB, Turan GA, Akan Z, Hasdemir SP. The association of HLA-G and immune markers in recurrent miscarriages. J Matern Fetal Neonatal Med. 2016;29:3056-60.

14. Özgül Özdemir RB, Özdemir AT, Oltulu F, Kurt K, Yiğittürk G, Kurmaz C. A comparison of cancer stem cell markers and nonclassical major histocompatibility complex antigens in colorectal tumor and noncancerous tissues. Ann Diagn Pathol. 2016;25:60-3.

15. Amiot L, Ferrone S, Grosse-Wilde H, Seliger B. Biology of HLA$\mathrm{G}$ in cancer: a candidate molecule for therapeutic intervention? Cell Mol Life Sci. 2011;68:417-31.

16. Goldman-Wohl DS, Ariel I, Greenfield C, Hanoch J, Yagel S. HLA-G expression in extravillous trophoblasts is an intrinsic property of cell differentiation: a lesson learned from ectopic pregnancies. Mol Hum Reprod. 2000;6:535-40.

17. Alsaab HO, Sau S, Alzhrani R, Tatiparti K, Bhise K, Kashaw SK, et al. PD-1 and PD-L1 Checkpoint Signaling Inhibition for Cancer Immunotherapy: Mechanism, Combinations, and Clinical Outcome. Front Pharmacol. 2017;8:561.

18. Buchbinder EI, Desai A. CTLA-4 and PD-1 Pathways. Am J Clin Oncol. 2016;39:98-106.

19. Francisco LM, Sage PT, Sharpe AH. The PD-1 Pathway in Tolerance and Autoimmunity. Immunol Rev. 2010;236:219-42.

20. Soliman H, Mediavilla-Varela M, Antonia S. Indoleamine 2,3dioxygenase: is it an immune suppressor? Cancer J Sudbury Mass. 2010;16:354-9.

21. Routy J-P, Routy B, Graziani GM, Mehraj V. The Kynurenine Pathway Is a Double-Edged Sword in Immune-Privileged Sites and in
Cancer: Implications for Immunotherapy. Int $\mathrm{J}$ Tryptophan Res. 2016;9:67-77.

22. Takikawa O, Tagawa Y, Iwakura Y, Yoshida R, Truscott RJW Interferon-Gamma-Dependent/Independent Expression of Indoleamine 2,3-Dioxygenase. Adv Exp Med Biol. 1999;467:553-7.

23. Bukur J, Jasinski S, Seliger B. The role of classical and nonclassical HLA class I antigens in human tumors. Semin Cancer Biol. 2012;22:350-8.

24. He X, Dong D, Yie S, Yang H, Cao M, Ye S, et al. HLA-G expression in human breast cancer: implications for diagnosis and prognosis, and effect on allocytotoxic lymphocyte response after hormone treatment in vitro. Ann Surg Oncol. 2010;17:1459-69.

25. Ozgul Ozdemir RB, Ozdemir AT, Oltulu F, Kurt K, Yigitturk G, Kirmaz C. The Expressions of Cancer Stem Cell Markers and Nonclassical HLA antigens in Breast Tumors. Istanb Med J. 2017;18:128-34.

26. Elliott RL, Jiang XP, Phillips JT, Barnett BG, Head JF. Human leukocyte antigen $\mathrm{G}$ expression in breast cancer: role in immunosuppression. Cancer Biother Radiopharm. 2011;26:153-7.

27. Pangault C, Amiot L, Caulet-Maugendre S, Brasseur F, Burtin F, Guilloux V, Drenou B, Fauchet R, Onno M. HLA-G protein expression is not induced during malignant transformation. Tissue Antigens. 2002;53:335-46.

28. Mazel M, Jacot W, Pantel K, Bartkowiak K, Topart D, Cayrefourcq L, et al. Frequent expression of PD-L1 on circulating breast cancer cells. Mol Oncol. 2015;9:1773-82.

29. Rom-Jurek E-M, Kirchhammer N, Ugocsai P, Ortmann O, Wege AK, Brockhoff G. Regulation of Programmed Death Ligand 1 (PD-L1) Expression in Breast Cancer Cell Lines In Vitro and in Immunodeficient and Humanized Tumor Mice. Int J Mol Sci. 2018;13:19.

30. Castro F, Cardoso AP, Gonçalves RM, Serre K, Oliveira MJ. Interferon-Gamma at the Crossroads of Tumor Immune Surveillance or Evasion. Front Immunol. 2018;4;9.

31. Osum KC, Burrack AL, Martinov T, Sahli NL, Mitchell JS, Tucker CG, et al. Interferon-gamma drives programmed death-ligand 1 expression on islet $\beta$ cells to limit $\mathrm{T}$ cell function during autoimmune diabetes. Sci Rep. 2018;8:1-12.

32. Holmgaard RB, Zamarin D, Munn DH, Wolchok JD, Allison JP. Indoleamine 2,3-dioxygenase is a critical resistance mechanism in antitumor $\mathrm{T}$ cell immunotherapy targeting CTLA-4. J Exp Med. 2013;210:1389-402.

33. Munn DH, Mellor AL. IDO in the Tumor Microenvironment: Inflammation, Counter-Regulation, and Tolerance. Trends Immunol. 2016;37:193-207.

34. Larrain MTI, Rabassa ME, Lacunza E, Barbera A, Cretón A, Segal-Eiras A, et al. IDO is highly expressed in breast cancer and breast cancer-derived circulating microvesicles and associated to aggressive types of tumors by in silico analysis. Tumor Biol. 2014;35:6511-9.

35. Wei L, Zhu S, Li M, Li F, Wei F, Liu J, Ren X. High Indoleamine 2,3-Dioxygenase Is Correlated With Microvessel Density and Worse Prognosis in Breast Cancer. Front Immunol. 2018;9:724. 